\title{
The influence of filter-feeding benthic macroinvertebrates on the transport and deposition of particulate organic matter and diatoms in two streams
}

\author{
Michael T. Monaghan, ${ }^{1}$ Steven A. Thomas, ${ }^{2}$ and G. Wayne Minshall \\ Department of Biological Sciences, Idaho State University, Pocatello, Idaho 83209
}

\section{J. Denis Newbold}

Stroud Water Research Center, Avondale, Pennsylvania 19311

\section{Colbert E. Cushing}

Department of Fishery and Wildlife Biology, Colorado State University, Fort Collins, Colorado 80523

\begin{abstract}
The transport and deposition of particulate organic matter (POM) in streams has received much attention in recent years. As with many ecosystem processes, determining the relative importance of physical and biological mechanisms for POM removal (e.g., sedimentation and filter-feeding) remains an important task. We examined the influence of benthic filter-feeding Hydropsyche and Simuliidae on downstream transport distance $\left(S_{P}\right)$ and deposition rate $\left(v_{\text {dep }}\right)$ of POM in two streams. We conducted five field experiments using radiolabeled $\left({ }^{14} \mathrm{C}\right)$ natural detritus and living diatoms (Asterionella) to measure longitudinal loss $\left(k_{P} \mathrm{~m}^{-1}=1 / S_{P}\right)$ before and after complete removal of filter-feeding benthic macroinvertebrates. $k_{P}$ decreased following filter-feeder removal in each experiment, although meta-analysis indicated no consistent nonzero effect. However, the changes in $k_{P}$ were within the range to be expected from previously published rates of capture by the filter-feeders, indicating limited statistical power. We also examined uptake of radiolabeled POM by filter-feeders in three of the experiments. Simuliidae radioactivity increased significantly during two of the three releases of POM, although uptake accounted for up to $11 \%$ of wholestream POM deposition. Our results suggest that transported POM and diatoms are deposited from the water column rapidly and that mechanisms other than filter-feeding by invertebrates are responsible for most of the transfer of POM from the water column to the sediments of streams.
\end{abstract}

Capture and ingestion of suspended particulate organic matter (POM) by benthic filter-feeders is one pathway through which carbon and nutrients are transferred from the water column to the sediments, resulting in their retention, utilization, and cycling (Wallace et al. 1977; Wallace and Merritt 1980; Newbold et al. 1982; Dame et al. 1984; Nakamura et al. 1988; Wotton 1994; Prins et al. 1998). In

\footnotetext{
${ }^{1}$ To whom correspondence should be addressed. Present address: Department of Limnology, EAWAG/ETH, 8600 Dübendorf, Switzerland (monaghan@eawag.ch).

${ }^{2}$ Present address: Department of Biology, Virginia Polytechnic Institute and State University, Blacksburg, Virginia 24061.

\section{Acknowledgments}

For field and laboratory assistance, we thank Ken Aho, Kristen Bohn, Kate Bowman, Angela Bright, Adrienne Crowly, Christine Fischer, Jeff Horsley, Jamie Larsen, Judy Minshall, Cary Myler, Erin O'Leary-Jepson, Deborah Orcutt, Gigi Ostrow, Mark Overfield (now deceased), Christina Relyea, Scott Relyea, Todd Royer, Kelly Sant (now deceased), Joe Sirotnak, Jesse Schomberg, Eric Snyder, Michele Thornton, and Jeff Varricchionne. We appreciate Jacqueline Schnurr's additional assistance with diatom collection and radiolabeling and the statistical advice of Peter Curtis, Jessica Gurevitch, and Sandra Lass. Dave Arscott provided comments on a previous version, and the comments and suggestions of Margaret Palmer and two anonymous referees substantially improved the manuscript. A special thanks goes to Ted Georgian for his assistance and encouragement. Research was funded by grant DEB-9306365 from the U.S. National Science Foundation and grant S97-07 from the Idaho State University Graduate Research and Scholarship Committee.
}

streams, where planktonic utilization of material is minimal, retention by benthic filter-feeders may be a particularly important mechanism in material cycling and may have important consequences for the longitudinal and vertical flux of particulate material. Likewise, filter-feeder capture of POM also may result in significant depletion or alteration of their own food resource. Such effects may be local (Fréchette and Bourget 1985) or propagated downcurrent (Maciolek and Tunzi 1968; Peterson and Black 1987; Morin et al. 1988), thereby limiting resource availability to other filterfeeders.

Studies of coastal embayments, large shallow rivers, and estuaries have implicated bivalves as the cause of significant alterations to the abundance of suspended material in nearbed layers or in the entire water body (Cloern 1982; Nakamura et al. 1988; Wilkinson et al. 1996; Welker and Walz 1998; Strayer et al. 1999). In streams (including smaller, unregulated rivers), where turbulent mixing and downstream advection are organizing physical features, the magnitude of filter-feeder influence on local and downstream conditions may be comparatively small. Several studies in small streams have documented varying degrees of filter-feeder influence (e.g., Sheldon and Oswood 1977; Wallace and Merritt 1980), and some have even postulated longitudinal selflimitation (Naiman 1983; Parker and Voshell 1983).

Published investigations of benthic filter-feeder-POM interactions in freshwater and marine ecosystems can be divided into two methodological categories. The first method 
of investigation measures ingestion rates and extrapolates to whole ecosystems using density estimates (e.g., Georgian and Wallace 1981; Bunt et al. 1993). The second method determines net upstream-downstream changes in quantitative and qualitative characteristics of transported POM passing over invertebrate populations. In streams, ingestion studies have reported POM capture rates ranging from 0.005 to $0.01 \%$ POM lost per longitudinal meter traveled (McCullough et al. 1979a,b; Georgian and Wallace 1981; Haefner and Wallace 1981; Georgian and Thorp 1992). Upstream-downstream studies have documented an ability of filter-feeders to remove significant portions of suspended POM and to alter the size composition of particles remaining in the water column (e.g., Wotton 1992; Hershey et al. 1996; Wotton et al. 1996). For example, Wotton et al. (1998) estimated that $13 \%$ of transported POM in a $220-\mathrm{m}$ reach of stream was lost to filter-feeding Simuliidae-a loss rate of $0.06 \% \mathrm{~m}^{-1}$. Maciolek and Tunzi (1968) and Welker and Walz (1998) estimated that nearly all lentic plankton transported downstream in two lake outlets were removed by filter-feeders. Morin et al. (1988) combined ingestion and upstream-downstream methods and examined POM concentration before and after removal of Simuliidae from a study stream. They attributed $0.8-1.4 \%$ loss per meter of suspended material to filter-feeder capture.

One question arising from the research summarized above is how significant these values are relative to other pathways of POM deposition. Recently, studies of POM transport and deposition have been conducted using experimental additions of radioactively labeled natural detritus (Cushing et al. 1993; Minshall et al. 2000; Thomas et al. in press), seston analogs (Miller and Georgian 1992; Webster et al. 1999), and fluorescently labeled bacteria (Hall et al. 1996). Cushing et al. (1993) and Minshall et al. (2000) observed total instream loss rates ranging from 0.15 to $17.14 \%$ per longitudinal meter for POM between 52 and $106 \mu \mathrm{m}$ in size. These values are equivalent to downstream transport distances, $S_{P}$, of 5.8-667 m, where $S_{P}$ equals the inverse of the longitudinal loss rate $\left(S_{P}=1 / k_{P}\right)$. Miller and Georgian (1992) observed $k_{P}$ values of $0.52-0.82 \% \mathrm{~m}^{-1}$ for corn pollen, and Webster et al. (1999) determined losses of $0.7-25 \% \mathrm{~m}^{-1}$ for corn pollen and $3.6-50 \% \mathrm{~m}^{-1}$ for glass beads. Hall et al. (1996) observed loss rates of $1.2-1.3 \% \mathrm{~m}^{-1}$ for bacteria and suggested that filter-feeders were responsible for just over $6 \%$ of bacterial deposition. Thus, studies of seston deposition report loss rates that are one to three orders of magnitude more rapid than studies of capture rates or net upstreamdownstream changes in the transported POM pool. Together, these results highlight the need for a more comprehensive assessment of the relative importance of filter-feeding activity as a mechanism of POM deposition in streams.

In this research, we combined several of the approaches discussed above to evaluate the hypothesis that filter-feeding benthic macroinvertebrates (Hydropsyche and Simuliidae) have the ability to influence stream seston concentrations. We conducted five experiments in which we measured longitudinal loss rate $\left(k_{P}\right)$ and calculated deposition velocity $\left(v_{\text {dep }}\right)$ of natural POM and live diatoms (radiolabeled with ${ }^{14} \mathrm{C}$ ) before and after complete removal of filter-feeding macroinvertebrates from streams. We then compared these val-
Table 1. Physical characteristics of DC and UBC as point measurements made during each experiment. Flow conditions changed between the pre- and postremoval phases of the UBC 1997 experiment and are presented separately.

\begin{tabular}{lcccc}
\hline \hline Study site & $\begin{array}{c}\text { Discharge } \\
\left(\mathrm{L} \mathrm{s}^{-1}\right)\end{array}$ & $\begin{array}{c}\text { Velocity } \\
\left(\mathrm{m} \mathrm{s}^{-1}\right)\end{array}$ & $\begin{array}{c}\text { Width } \\
(\mathrm{m})\end{array}$ & $\begin{array}{c}\text { Depth } \\
(\mathrm{m})\end{array}$ \\
\hline DC & 12.6 & 0.14 & 2.1 & 0.05 \\
UBC 1996 & 3.5 & 0.09 & 0.56 & 0.07 \\
UBC 1997 & & & & \\
Pre & 2.8 & 0.05 & 0.58 & 0.10 \\
Post & 4.4 & 0.05 & 0.68 & 0.13 \\
\hline
\end{tabular}

ues to published rates of physiological uptake and examined whether POM transport consistently was altered by filterfeeders using a meta-analysis of multiple experiments. Additionally, we measured the direct uptake of radiolabeled POM and diatoms by filter-feeding Simuliidae to compare with whole-stream deposition of POM. The specific objective was to quantify the influence of filter-feeders on longitudinal loss rate $\left(k_{P}\right)$, transport distance $\left(S_{P}\right)$, and field deposition velocity $\left(v_{\text {dep }}\right)$ of two size fractions of particulate detritus and of live diatoms.

\section{Methods}

We conducted five experiments that quantified the influence of filter-feeding benthic macroinvertebrates upon transported POM. Two experiments examined VFPOM (very fine particulate organic matter; 15-52 $\mu \mathrm{m}$ ); one examined live, planktonic diatoms (Asterionella $>52 \mu \mathrm{m}$ ); and two examined FPOM $(52-106 \mu \mathrm{m})$. Each experiment consisted of six steps: (1) collecting natural suspended material; (2) radioactively labeling the POM and diatoms using ${ }^{14} \mathrm{C}$; (3) metering the labeled VFPOM, Asterionella, or FPOM into a stream; (4) measuring the longitudinal (downstream) loss from the water column; (5) removing the filter-feeding benthic macroinvertebrates from each study reach; and (6) repeating steps 3 and 4 . In three of the experiments, individual filter-feeders were removed from the substratum during each preremoval release (step 3) to measure uptake of labeled particles.

Site descriptions and filter-feeder sampling-We conducted one FPOM experiment in Deep Creek (DC) in Oneida County, Idaho $\left(112^{\circ} 40^{\prime} \mathrm{W}, 42^{\circ} 8^{\prime} \mathrm{N}\right)$. DC is a low gradient (slope $=1 \%$ ), cold desert spring stream in which filter-feeding Hydropsyche larvae occur in high densities and comprise much of the biomass of benthic macroinvertebrates (McCullough et al. 1979a). The experiment was conducted during reduced flows when water was diverted from DC into an irrigation canal, reducing discharge from 800-900 L s to $12-20 \mathrm{~L} \mathrm{~s}^{-1}$ (for discharge during the experiment, see Table 1). Four experiments were conducted in upper Bloomington Creek (UBC) in Bear Lake County, Idaho $\left(111^{\circ} 34^{\prime} \mathrm{W}, 42^{\circ} 8^{\prime} \mathrm{N}\right)$. UBC is a high gradient, lake outlet stream (slope $=14 \%$ ) containing filter-feeding Simuliidae. Discharge during the experiments ranged from 2.7 to $4.4 \mathrm{~L}$ $\mathrm{s}^{-1}$. We conducted one experiment in UBC in 1996 using 
VFPOM. We conducted three experiments here in 1997, one each with VFPOM, Asterionella diatoms, and FPOM. We investigated the uptake of radiolabeled particles by Simuliidae at UBC during the 1997 preremoval releases. Physical characteristics of both study streams (Table 1) were measured in the field and calculated using hydrologic tracer data (see Minshall et al. 2000).

Benthic macroinvertebrates were collected from DC $(n=$ 6) with a modified Hess sampler (707 $\mathrm{cm}^{2}, 250-\mu \mathrm{m}$ mesh) $24 \mathrm{~h}$ prior to the preremoval release. In UBC, samples $(n=$ 10) were taken $24 \mathrm{~h}$ after the preremoval releases with a specially constructed Surber sampler, consisting of a small $\left(154 \mathrm{~cm}^{2}\right)$ frame with an attached $250-\mu \mathrm{m}$ mesh net. Rocks were brushed by hand and examined carefully to ensure all Simuliidae were removed. All samples were preserved in a $4 \%$ formalin solution in the field and returned to the laboratory, where filter-feeders were separated, enumerated, dried in a $60^{\circ} \mathrm{C}$ oven, and weighed (mg DM) using a Cahn ${ }^{\odot}$ model 25 electrobalance.

Collection and release of radiolabeled particles-Suspended POM was collected from the study sites and radiolabeled using $\left[{ }^{14} \mathrm{C}\right]$ dimethyl sulfate as described by Minshall et al. (2000). Size fractionation of POM was conducted using standard sieves $(15,52$, and $106 \mu \mathrm{m})$ prior to radiolabeling. Diatoms were collected from surface tows on Bloomington Lake (using a $52-\mu \mathrm{m}$ mesh net) and radiolabeled by an $8-\mathrm{d}$ incubation in a solution of lake water spiked with $\left({ }^{14} \mathrm{C}\right)$ sodium bicarbonate. Prior to release into the stream, solution aliquots examined under a microscope indicated that the predominant taxon was Asterionella. Field releases of POM and diatoms were performed using the techniques described by Minshall et al. (2000). In DC, $\approx 5$ liters of stream water containing $15 \mathrm{ml}$ rhodamine WT (water tracer) and labeled particles was metered into the stream for $10 \mathrm{~min}$. In UBC, 1.0-2.8 liters of stream water with radiolabeled material and 3-6 ml rhodamine WT were metered in over a period of 6.5-15 min. Values varied because of adjustments made for different discharge volumes.

Longitudinal loss rate and deposition velocity-Water samples were examined for ${ }^{14} \mathrm{C}$ and rhodamine WT concentration as described by Minshall et al. (2000). Grab samples $(250 \mathrm{ml})$ were taken simultaneously at multiple downstream transects (five in DC, four in UBC; see Fig. 1) at timed intervals during each release. The amount of labeled material passing each downstream transect was calculated by timeintegrating dilution-corrected ${ }^{14} \mathrm{C}$ concentration over the entire passage of the release pulse (Stream Solute Workshop 1990). The longitudinal loss rate of radiolabeled material $\left(k_{P}\right)$ was determined using $F_{(x)}=F_{(0)} \exp \left(-k_{P} x\right)$, where $F_{(x)}$ represents the amount of ${ }^{14} \mathrm{C}$ remaining at each downstream distance $x$, and $F_{(0)}$ represents the amount of ${ }^{14} \mathrm{C}$ added to the stream (Newbold et al. 1991). Nonlinear regression was used to fit the equation to the dilution-corrected ${ }^{14} \mathrm{C}$ versus distance plot for each release (Fig. 1). Nonlinear fits were reasonably good descriptors of the data (all $r^{2}>0.95$ ), although standard errors of the regression were large (see Results). Mean transport distance $\left(S_{P}\right)$ of material was calculated as the inverse of $k_{P}$, and field deposition velocity $\left(v_{\text {dep }}\right)$
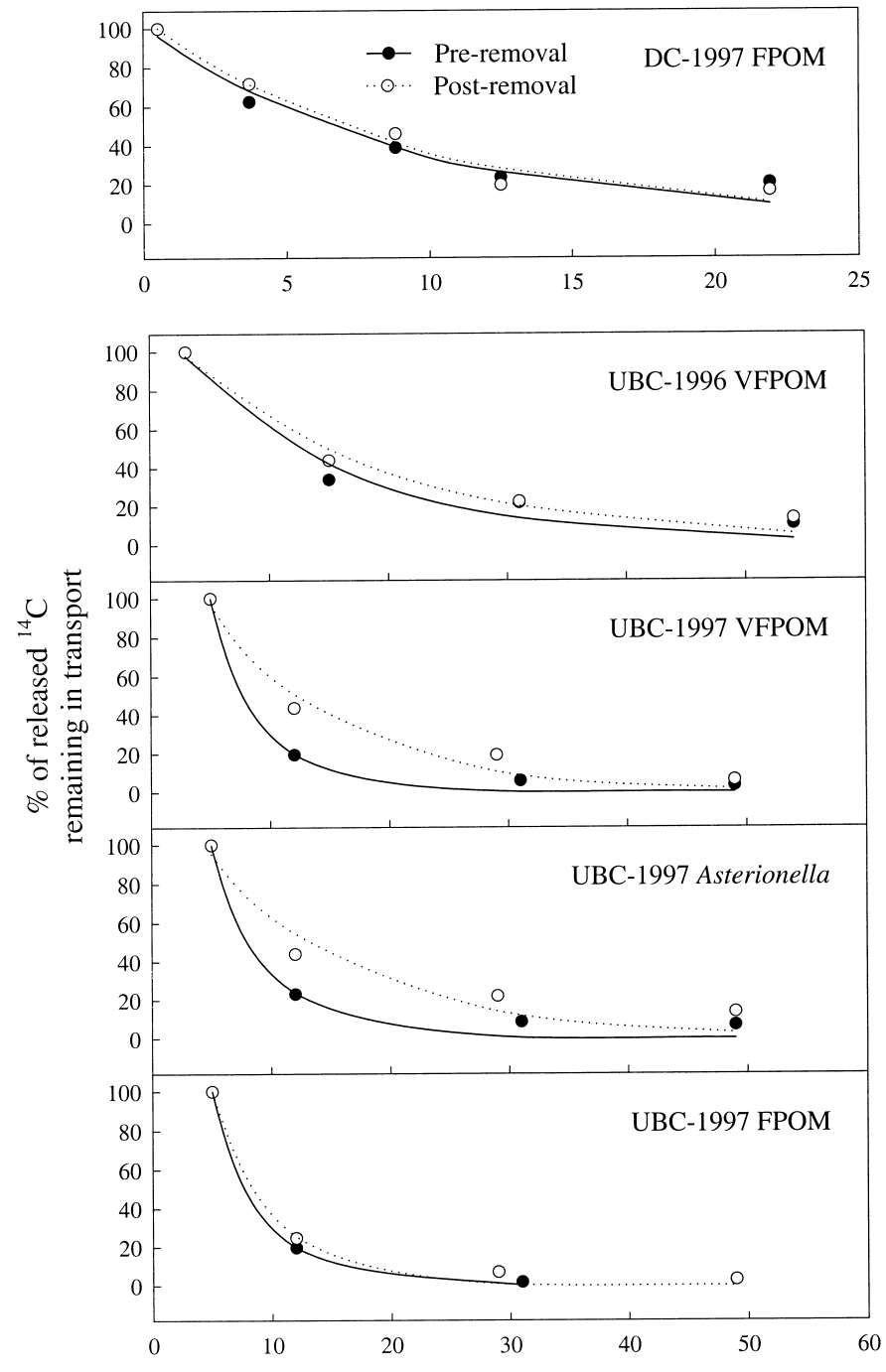

Downstream distance $(\mathrm{m})$

Fig. 1. Amount of ${ }^{14} \mathrm{C}$ remaining in transport at each downstream station and nonlinear regression lines for each pre- and postremoval release in DC and in UBC.

was calculated as $v_{\text {dep }}=k_{P} \cdot u \cdot h$, where $u$ is mean water velocity, and $h$ is the mean depth of the entire reach (Table 1). Preremoval FPOM data were reported by Minshall et al. (2000) as part of a study of physical factors influencing POM deposition, and preremoval of VFPOM and Asterionella were reported by Thomas et al. (in press) for an investigation of multiple POM sizes and types.

Calculated rate of POM uptake by filter-feeders-We used the change in deposition velocity, $\Delta v_{\text {dep }}$ in millimeters per second, between pre- and postremoval measurements and biomass data from the benthic samples to back-calculate the rates of particle capture by filter-feeders. We then compared these with published rates of uptake for the same taxa. We calculated this capture rate $\left(C\right.$, in $\mu \mathrm{g}$ POM mg dry mass ${ }^{-1}$ $\left.\min ^{-1}\right)$ as $C=60 \cdot \mathrm{POM} \cdot \Delta v_{\mathrm{dep}} / B_{\mathrm{FF}}$, where POM is the concentration of suspended particles $\left(\mu \mathrm{g} \mathrm{m}^{-3}\right)$ in the exper- 
Table 2. Transport and deposition parameters measured during pre- and postremoval releases in DC and UBC; $k_{P}$, longitudinal loss rate with $95 \%$ confidence intervals; $\delta$, effect size calculated for the meta-analysis; $S_{P}$, transport distance; $v_{\text {dep }}$, deposition velocity; $\Delta v_{\text {dep }}$, the difference calculated between pre- to postremoval $v_{\text {dep }}$.

\begin{tabular}{|c|c|c|c|c|c|c|c|}
\hline Experiment & Release & $k_{P}\left(\mathrm{~m}^{-1}\right)$ & $95 \% \mathrm{CI}$ & $\delta$ & $S_{P}(\mathrm{~m})$ & $\begin{array}{c}v_{\mathrm{dep}} \\
\left(\mathrm{mm} \mathrm{s}^{-1}\right)\end{array}$ & $\begin{array}{c}\Delta v_{\text {dep }} \\
\left(\mathrm{mm} \mathrm{s}^{-1}\right)\end{array}$ \\
\hline \multirow[t]{2}{*}{ DC 1997 FPOM } & preremoval & 0.108 & 0.140 & 0.041 & 9.3 & 0.66 & \\
\hline & postremoval & 0.106 & 0.132 & & 9.5 & 0.64 & 0.02 \\
\hline UBC 1996 VFPOM & postremoval & 0.055 & 0.067 & & 18.1 & 0.32 & 0.11 \\
\hline \multirow[t]{2}{*}{ UBC 1997 VFPOM } & preremoval & 0.229 & 0.355 & 1.313 & 4.4 & 1.08 & \\
\hline & postremoval & 0.092 & 0.135 & & 10.9 & 0.60 & 0.48 \\
\hline \multirow[t]{2}{*}{ UBC 1997 FPOM } & preremoval & 0.232 & 0.255 & 0.578 & 4.3 & 1.10 & \\
\hline & postremoval & 0.195 & 0.249 & & 5.1 & 1.27 & -0.17 \\
\hline Mean $\delta$ & & & & 0.335 & & & \\
\hline $95 \% \mathrm{CI}$ & & & & 0.598 & & & \\
\hline
\end{tabular}

imental reach in the size fraction (e.g., VFPOM) of interest, and $B_{\mathrm{FF}}$ is filter-feeder biomass $\left(\mathrm{mg} \mathrm{m}^{-2}\right)$. Values of $\Delta v_{\text {dep }}$ are from Table 2.

Calculated whole-stream deposition of ${ }^{14} \mathrm{C}$-We calculated whole-stream POM deposition during each of the releases at UBC in 1997 using in-stream ${ }^{14} \mathrm{C}$ concentration and $k_{P}$. We then compared this with total observed ${ }^{14} \mathrm{C}$ uptake by Simuliidae (measured as described below). For the calculation, the absolute amount of ${ }^{14} \mathrm{C}$ leaving the water column between 30 and $31 \mathrm{~m}$ below the release point (the location of the Simuliidae) was calculated with the same equation used to fit the release data and the empirical values of $k_{P}$ listed in Table 2. For the comparison, total deposition was standardized by the number of Simuliidae larvae present in that longitudinal meter of stream (calculated by dividing Simuliidae density by stream width).

Filter-feeder removal-Following the preremoval releases, filter-feeders were removed from each study site using

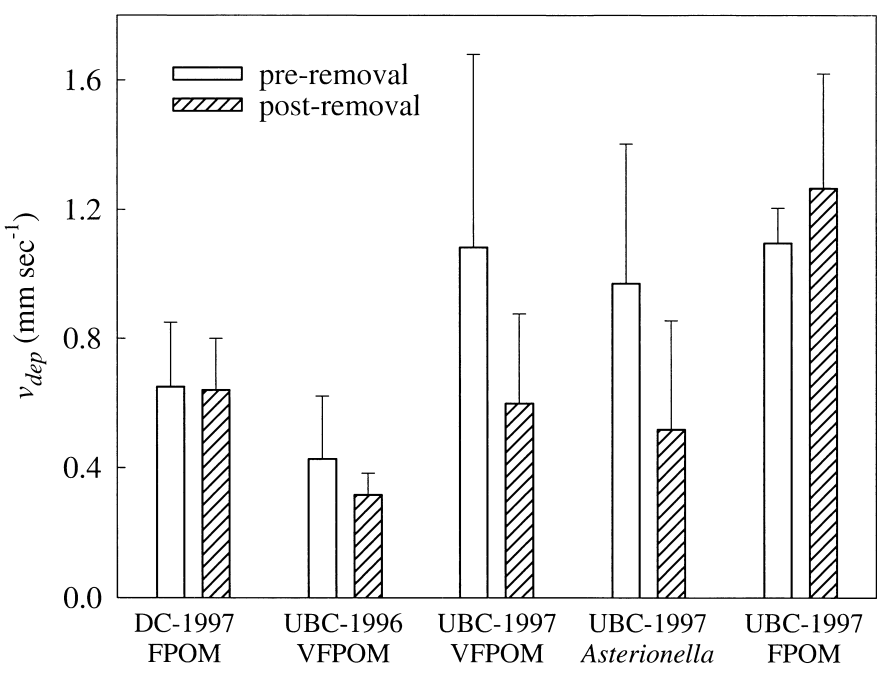

Fig. 2. Calculated estimates of $v_{\text {dep }}$ and $95 \%$ confidence intervals for each pre- and postremoval release of particles. chemical methods to minimize disturbance to the stream bottom, i.e., to any other biotic and abiotic POM retention mechanisms. In DC, all benthic macroinvertebrates were killed or removed by adding sodium metabisulfite $\left(\mathrm{Na}_{2} \mathrm{~S}_{2} \mathrm{O}_{5}\right)$ to the stream. $\mathrm{Na}_{2} \mathrm{~S}_{2} \mathrm{O}_{5}(45.4 \mathrm{~kg})$ was dissolved in stream water (180 liters), and the solution was metered into the stream for $4 \mathrm{~h}$. The resulting in-stream concentration of $\mathrm{Na}_{2} \mathrm{~S}_{2} \mathrm{O}_{5}$ was $250 \mathrm{mg} \mathrm{L}^{-1}$ and lowered the dissolved oxygen concentration from 8.0 to $0.0-0.2 \mathrm{mg} \mathrm{L}^{-1}$ within a reach length of $\approx 200 \mathrm{~m}$ for slightly $<4 \mathrm{~h}$. Many benthic macroinvertebrates drifted immediately upon exposure to depleted oxygen levels, but previous experience had shown that $H y$ dropsyche resisted drifting when exposed to an acute pulse of low dissolved oxygen, withstanding $0.0 \mathrm{mg} \mathrm{L}^{-1}$ for up to $20 \mathrm{~min}$. The 4-h injection ensured either drift or mortality. Following the $\mathrm{Na}_{2} \mathrm{~S}_{2} \mathrm{O}_{5}$ injection, additional Hess samples were collected. Densities were drastically reduced, and those macroinvertebrates that did remain were dead. All Hydropsyche nets that were observed were destroyed, presumably because of a lack of maintenance (Fuller et al. 1983). We assume no significant colonization occurred in the $24 \mathrm{~h}$ between the removal and the next release of labeled particles.

In UBC, filter-feeding black flies were killed in both 1996 and 1997 with an application of Bacillus thuringiensis var. israelensis (Bti). An aqueous suspension of Bti $(40 \mathrm{ml})$ was poured into the stream over a 1-min period. Twenty-four hours later, $93 \%$ of a sample of 217 individuals collected from the study reach was dead.

${ }^{14} \mathrm{C}$-Uptake by Simuliidae-During the preremoval releases at UBC in 1997, individual Simuliidae were removed using forceps from a single rock located $30 \mathrm{~m}$ downstream of the injection site. Individuals were placed into scintillation vials in groups of five, as we were unsure of radioactivity and wanted to ensure detection. Ten animals (i.e., $n=2$ ) were collected at $0,5,10,20,30$, and $40 \mathrm{~min}$ after the start of each release. For the VFPOM experiment, Simuliidae also were collected at 50 min (see Fig. 3). Additionally, five nonfiltering caddisflies (Neothrema: Limnephilidae) were collected in an identical manner from a stone immediately adjacent to the stone from which Simuliidae were removed. 


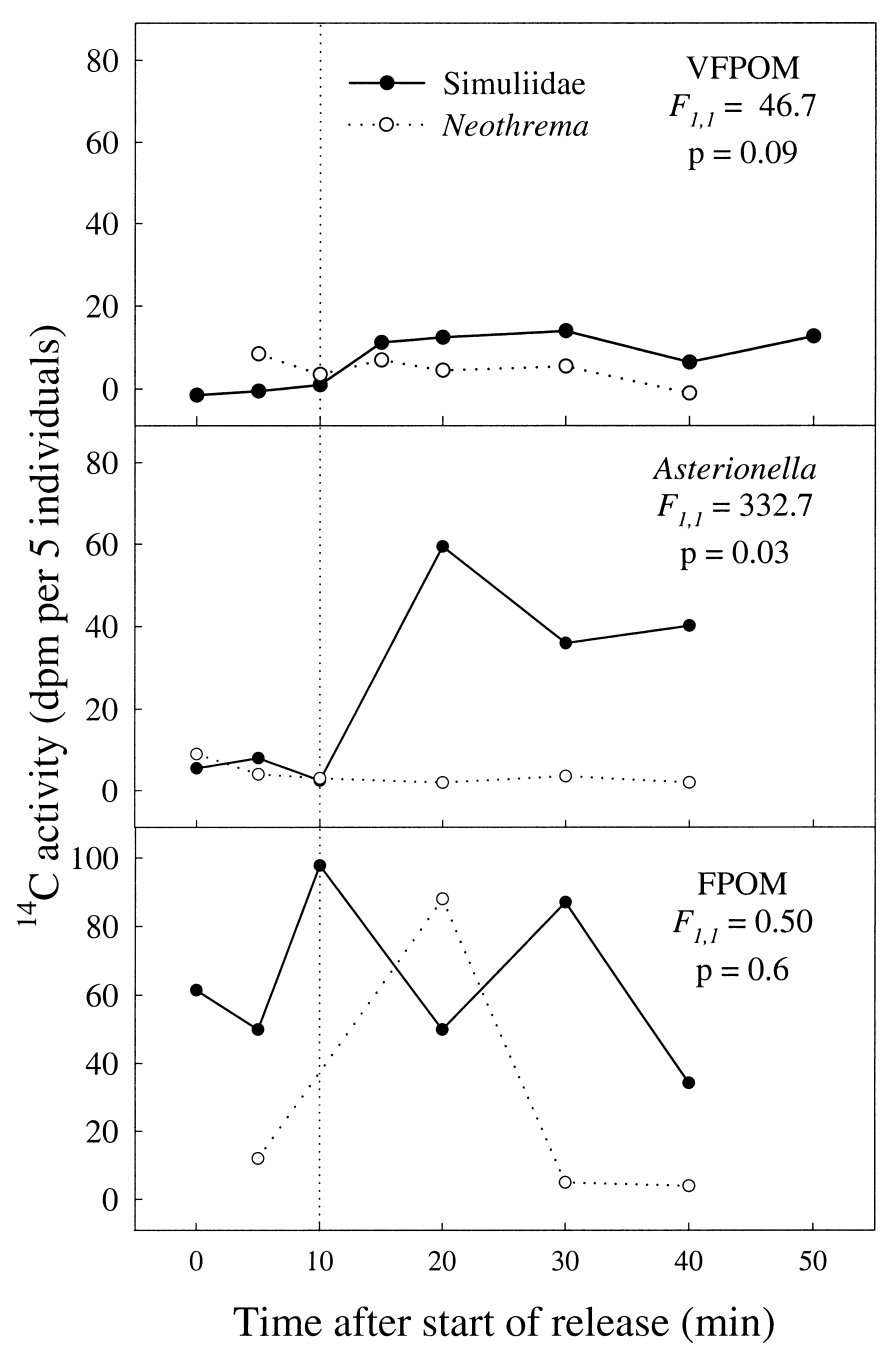

Fig. 3. ${ }^{14} \mathrm{C}$ uptake (measured as dpm per individual) observed in Simuliidae and Neothrema during the VFPOM, Asterionella, and FPOM releases in UBC in 1997. The dashed vertical line at $10^{\prime \prime}$ represents the time at which radiolabeled particles first reached the sample area (see text). Radioactivity levels to the left of this dashed line were used to calculate background, and levels to the right were compared between taxa using ANOVA, for which $F$ statistics and $P$ values are reported for each experiment.

Neothrema were collected and analyzed to examine whether ${ }^{14} \mathrm{C}$ was taken up by means other than capture from the water column. For both taxa, samples were removed individually from the downstream end of the sampling area, working upstream for each subsequent sample. In the field, samples were rinsed with distilled water onto a 5 - $\mu \mathrm{m}$ cellulose nitrate filter and placed in scintillation vials. Samples then were transported to the Stroud Water Research Center (Avondale, Pennsylvania) for ${ }^{14} \mathrm{C}$ analysis by combustion.

Statistical analyses-The five experiments examined a range of particle sizes and types and were conducted in two different streams at varying discharge. As such, we treated each as a separate experiment rather than as replicates and used a fixed-effect model meta-analysis procedure to examine whether or not there was a consistent, nonzero effect of filter-feeder removal on $k_{P}$ (Gurevitch and Hedges 1993). A meta-analysis approach was deemed most appropriate for the present study based on two criteria discussed by Arnqvist and Wooster (1995). First, changes in $k_{P}$ were expected to be small, based both on calculations for the present study (see Results, Calculated rate of POM uptake by filter-feeders, below) and on previous studies of filter-feeder capture (e.g., McCullough et al. 1979a,b). Second, sample size for each experiment was limited to one- a common attribute of experiments in which whole ecosystems are manipulated. For meta-analysis, an effect size $(\delta)$ was calculated for each experiment by dividing the change in $k_{P}$ (pre- to postmacroinvertebrate removal) by a pooled variance (using regression SEs) using equations from Gurevitch and Hedges (1993). We then calculated a weighted-average $\delta$ across the five experiments and its $95 \%$ confidence interval. We employed a fixed-effects model because of the relative similarity of experiments (Gurevitch and Hedges 1999). The nonindependence of pre- and posttreatment data remains a challenge for meta-analysis and may lead to underestimates of the standard error of the mean effect (Curtis and Gurevitch pers. comm.; Gurevitch and Hedges 1999). We were therefore conservative in our interpretation of $\delta$ and its $95 \%$ confidence intervals.

To examine Simuliidae capture of ${ }^{14} \mathrm{C}$ during the three preremoval releases at UBC in 1997, individuals removed prior to the passage of the release pulse were used to compute a background mean ${ }^{14} \mathrm{C}$ level (measured as disintegrations per minute; dpm) for each taxon. After the releases, water velocity was determined with the rhodamine WT data and indicated that transport time of material was $10 \mathrm{~min}$ to this sampling location. Therefore, larvae sampled 0 and 5 min from the start of the release were used to compute background, and those sampled at $10 \mathrm{~min}$ were used for neither background nor uptake estimates. Background was subtracted from each subsequent dpm value, and any values made negative were converted to zero. A repeated-measures analysis of variance (ANOVA) (Statistica, vers. 5.1, StatSoft) was used to compare $\log (x+1)$-transformed $\mathrm{dpm}$ values, with taxon (Simuliidae and Neothrema) and time (20, 30, and $40 \mathrm{~min}$ ) as effects.

\section{Results}

Filter-feeder densities-Filter-feeder distributions were clumped in both DC and UBC, so density data were $\log$ transformed to estimate mean and standard deviation. Mean density and $95 \%$ confidence intervals then were back-transformed (Sokal and Rohlf 1995) to calculate the rate of POM uptake by filter-feeders (see below). DC Hydropsyche density during the experiment was $\approx 400 \pm 800$ individuals $\mathrm{m}^{-2}$ (mean $\pm 95 \%$ CI). In UBC, Simuliidae density was $\approx 2,300$ $\pm 2,400$ individuals $\mathrm{m}^{-2}$ in 1996 and 2,800 $\pm 3,000$ individuals $\mathrm{m}^{-2}$ in 1997.

Filter-feeder influence on $\mathrm{k}_{\mathrm{P}}$ and $\mathrm{v}_{\text {dep }}$ - In all five experiments, estimated mean longitudinal loss rate of particles $\left(k_{P}\right)$ decreased following filter-feeder removal (Table 2). However, the $95 \%$ confidence intervals of the meta-analysis effect size $(\delta)$ included zero, indicating that the effect of filter- 
feeders on longitudinal loss rate was not significant (Table 2 ). The order of magnitude decrease in $k_{P}$ during the UBC experiments in 1997 was in part influenced by increases in stream depth and velocity (see Table 1) that confounded filter-feeder effect, although the lack of statistical significance indicates a type I error did not occur. Calculated values of $v_{\text {dep }}$ ranged from 0.32 to $1.27 \mathrm{~mm} \mathrm{~s}^{-1}$ among all releases (Table 2). $v_{\text {dep }}$ decreased following filter-feeder removal in four of the five experiments, but considerable overlap occurred between each pair of estimates based on $95 \%$ confidence intervals (Fig. 2).

Calculated rate of POM uptake by filter-feeders-Using $\Delta v_{\text {dep }}$ (Table 2), the calculated capture rate of POM by $\mathrm{Hy}_{-}$ dropsyche in DC was $0.15 \mu \mathrm{g} \mathrm{OM} \mathrm{mg} \mathrm{DM}{ }^{-1} \mathrm{~min}^{-1}$ (ranging from 0.07 to $0.24 \mu \mathrm{g} \mathrm{OM} \mathrm{mg} \mathrm{DM}^{-1} \mathrm{~min}^{-1}$ based on the $95 \%$ CI of biomass data). This value was lower but similar to that observed by McCullough et al. (0.510 $\mu \mathrm{g}$ OM mg $\left.\mathrm{DM}^{-1} \min ^{-1} ; 1979 a\right)$ in a study of uptake of diatoms and green algae by Hydropsyche in this same stream. It was an order of magnitude lower than that observed in a study of detritus and zooplankton uptake by a different caddisfly taxon (Cheumatopsyche parentum; Parker and Voshell 1983).

Calculated capture rate of POM by Simuliidae in UBC ranged from 5.41 $\mu \mathrm{g} \mathrm{OM} \mathrm{mg} \mathrm{DM}{ }^{-1} \mathrm{~min}^{-1}$ (1996 FPOM) to $13.73 \mu \mathrm{g}$ OM mg DM ${ }^{-1} \min ^{-1}$ (1997 VFPOM). These rates were higher than those observed by Morin et al. (1988; particles $>0.2 \mu \mathrm{m} ; 1.13-1.53 \mu \mathrm{g} \mathrm{mg} \mathrm{DM}^{-1} \mathrm{~min}^{-1}$ ) and McCullough et al. (1979a,b; diatoms and detritus of unreported size $0.2-1.33 \mu \mathrm{g}$ OM mg $\mathrm{DM}^{-1} \mathrm{~min}^{-1}$ ) but were similar to the range observed by Wotton (1978; powdered charcoal $10.1 \mu \mathrm{m} ; 10.8-14 \mu \mathrm{g}$ OM mg DM$\left.{ }^{-1} \min ^{-1}\right)$.

${ }^{14} \mathrm{C}$ taken up by Simuliidae and deposited to the benthos${ }^{14} \mathrm{C}$ activity was detected in Simuliidae during all three 1997 releases (Fig. 3), indicating that capture of radiolabeled particles occurred. The difference in uptake between filtering Simuliidae and nonfiltering Neothrema was significant during the Asterionella diatom release and marginally significant during the VFPOM release (Fig. 3; includes ANOVA results). During the FPOM release, activity was not different between the taxa, and Simuliidae activity during the release was not significantly different from background levels (Fig. 3).

Whole-stream deposition of VFPOM, Asterionella, and FPOM was, when standardized by Simuliidae density, 20.4, 18.5, and $11.7 \mathrm{dpm}$ per individual, respectively (Fig. 4). In the corresponding releases, measured Simuliidae uptake was 2.3, 1.6, and $0.0 \mathrm{dpm}$, accounting for 11,9 , and $0 \%$ of whole-stream deposition for VFPOM, Asterionella, and FPOM (e.g., 2.3/20.4 $\approx 11 \%$; Fig. 4).

\section{Discussion}

Contributions of filter-feeding to $\mathrm{k}_{\mathrm{P}}$ and $\mathrm{S}_{\mathrm{P}}$-Meta-analysis indicated that complete removal of filter-feeders did not have a statistically significant influence on the longitudinal loss rate of POM $\left(k_{P}\right)$ in these streams. This was despite order-of-magnitude differences in $k_{P}$ in two of the experiments. Large standard error terms associated with the non-

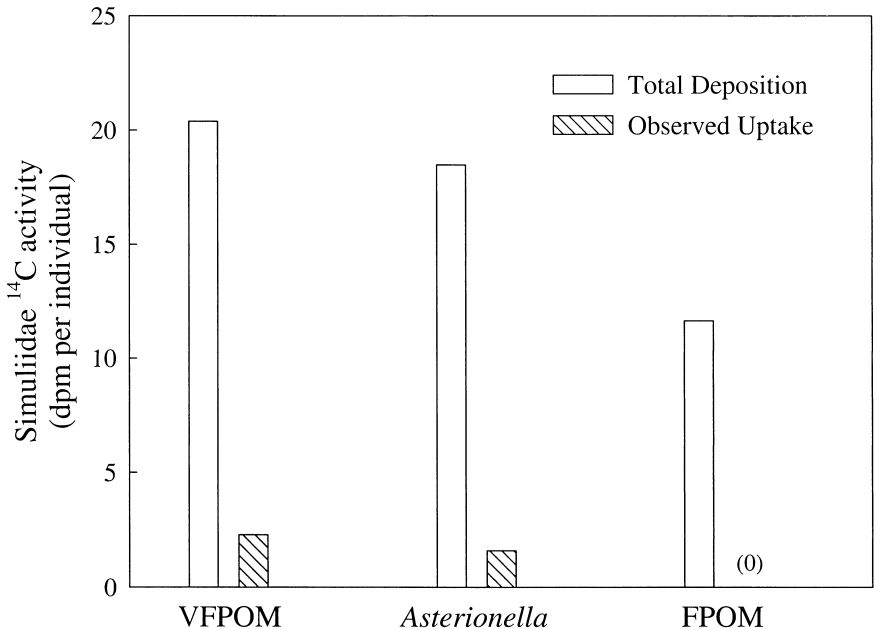

Fig. 4. Quantity of radiolabeled $\left({ }^{14} \mathrm{C}\right)$ POM expressed as activity per individual Simuliidae larva. Unfilled bars represent total, wholestream POM deposition that occurred during each release. Hatched bars indicate actual Simuliidae radioactivity.

linear regressions (as 95\% CI in Table 1), lack replication in our field experiments, and small relative changes in $k_{P}$ all contributed to the low statistical power of our analysis. However, considering that POM capture rates $\left(\mathrm{mg}^{-1}\right.$ filter-feeder dry mass) derived by back-calculating from the nonsignificant changes in $k_{P}$ were in close agreement with published values (e.g., Wotton 1978; McCullough et al. 1979a,b; Morin et al. 1988), we speculate that the observed changes in $k_{P}$ may have been real despite their lack of statistical significance.

The examination of numerical results, giving consideration to biological rather than statistical significance, allowed us to address the larger question of our research, namely, how important is filter-feeding relative to other processes of deposition. The presence of Hydropsyche in DC accounted for a longitudinal loss of $0.21 \% \mathrm{~m}^{-1}$. In comparison, the whole-stream loss rate was $10.8 \% \mathrm{~m}^{-1}$, indicating that $\mathrm{Hy}$ dropsyche was responsible for $\sim 3 \%$ of whole-stream deposition of FPOM in DC. This is despite $0.21 \%$ being the highest rate of longitudinal loss attributed to filtering caddisflies of which we are aware (e.g., Georgian and Wallace 1981; Parker and Voshell 1983). Stated another way, mean $S_{P}$ based only on Hydropsyche capture was $\sim 476 \mathrm{~m}$, while actual measured $S_{P}$ was only $9.3 \mathrm{~m}$. In UBC in 1996, changes in $k_{P}$ attributable to Simuliidae accounted for $26 \%$ of VFPOM deposition, with Simuliidae-specific $S_{P}$ equaling 50 $\mathrm{m}$ and actual $S_{P}$ equaling $13.4 \mathrm{~m}$. Thus, even a liberal interpretation of the data clearly indicates that processes other than filter-feeder capture account for the large majority of POM and diatom deposition that occurred. In UBC in 1997, changes in $k_{P}$ were confounded by increases in depth and velocity that occurred between pre- and postremoval releases. Comparisons of mean $v_{\text {dep }}$, which corrects for changes in water depth and velocity in its calculation, indicate a substantial influence of Simuliidae (up to $46 \%$; see Table 2). However, the large error involved in calculating this estimate also indicates that they may have had no influence. Thus, changes in transport and deposition of POM were difficult 
to detect in the field, and this low level of magnitude indicates influence was quite small relative to other mechanisms of POM deposition.

${ }^{14} \mathrm{C}$ uptake by Simuliidae and whole-stream depositionThe UBC 1997 experiments allowed us to examine filterfeeder influence on POM by comparing whole-stream POM deposition with Simuliidae capture. Simuliidae directly captured radiolabeled particles, indicated by detectable increases in radioactivity during releases of Asterionella and VFPOM. ${ }^{14} \mathrm{C}$ activity also was detected during the FPOM release but did not increase during the release, indicating that the individuals incorporated radiolabel from the two prior releases but not during the FPOM release. The two releases in which ${ }^{14} \mathrm{C}$ uptake was observed (VFPOM and Asterionella) also were the two experiments in which changes in particle $v_{\text {dep }}$ were observed in 1997, providing further evidence that the change in $k_{P}$ may have reflected actual filtering activity despite the lack of statistical significance. Nevertheless, comparisons of whole-stream ${ }^{14} \mathrm{C}$ deposition with actual Simuliidae activity indicated that uptake accounted for only 11 , 9 , and $0 \%$ of total deposition that actually occurred for VFPOM, Asterionella, and FPOM, respectively. These data again indicate that POM deposition is rapid and occurs mostly through mechanisms other than filter-feeder capture.

The ${ }^{14} \mathrm{C}$ uptake data indicated that Simuliidae were selectively removing particles during the releases (i.e., VFPOM and Asterionella but not FPOM). It is unlikely that the differential selection in uptake was the result of size selectivity because Asterionella and FPOM were retained in identical sieves $(52 \mu \mathrm{m})$. Asterionella colonies can reach diameters of $160 \mu \mathrm{m}$ (see Canter-Lund and Lund 1995); thus, the possibility exists that Asterionella and FPOM were differently distributed within a 52-160- $\mu \mathrm{m}$ size range (FPOM was 52$106 \mu \mathrm{m})$. However, the living Asterionella population released during this experiment likely contained colonies throughout this size range. Additionally, a large number of studies have failed to observe size fraction selection among particles $0.1-1,000 \mu \mathrm{m}$ by black fly larvae (reviewed by Wallace and Merritt 1980). Particle selectivity, including more general mechanisms such as particle quality or consistency, temporal variability in feeding activity, or both, requires further investigation.

Statistical power and ecosystem manipulation-The examination of multiple particle types and the manipulation of whole streams lessened our ability to detect small changes in $k_{P}$ as being statistically significant. In fact, order-of-magnitude differences in $k_{P}$ in some of the experiments (UBC 1997 VFPOM, Asterionella) were statistically insignificant. Reported values of $k_{P}$ for POM of various sizes span three orders of magnitude (see Thomas et al. in press), so the ability to detect marginal differences may be important for future work attempting to elucidate important mechanisms governing transport and deposition of both particulate and dissolved materials in streams. Standard error terms for the nonlinear model fit could be reduced by increasing the number of sampling transects and by sampling more frequently to minimize noise in the data. In particular, transects close to the release point are critical because of their importance in fitting logistic models.

\section{Conclusions}

We conclude that transported particles, including living planktonic diatoms, were deposited from the water column rapidly $\left(k_{P}\right.$ values reported here; Thomas et al. in press; see also Köhler and Bosse 1998) and that processes other than filter-feeding account for the majority of deposition to the sediments. A strictly numerical analysis of changes in $k_{P}$ indicated that $3-26 \%$ of particle deposition was the result of filter-feeder capture. Lack of statistical significance for these values indicates that experimental methodology for such work requires more intensive sampling to reduce standard error, although studies using ecosystem manipulation always will be faced with inherent lack of replication. Based on statistically significant ${ }^{14} \mathrm{C}$ uptake data, filter-feeders were responsible for $0-11 \%$ of all deposition that occurred in these streams. These more conservative results compare favorably with those of Hall et al. (1996), who determined that filter-feeding Simuliidae accounted for slightly $>6 \%$ of the total deposition of fluorescently labeled bacteria in a North Carolina mountain stream.

We conclude that filter-feeder capture likely is a relatively small component of POM deposition in most streams and explains only a small amount (up to $\sim 10 \%$ ) of the variation of POM $v_{\text {dep }}$ that occurs in nature. Minshall et al. (2000) and Thomas et al. (in press) have found strong empirical relationships between $v_{\text {dep }}$ and certain physical characteristics of streams (e.g., the relative extent of transient storage) and have speculated that additional, unexplained variation of $v_{\text {dep }}$ may be the result of biotic processes. In this field examination of two streams and multiple particle sizes and types, two predominant arthropod filterers in stream ecosystems had, at most, a minor influence. In addition to future work on filter-feeders described above, additional investigations of the role of macrophytes (e.g., Chandler 1937) and biofilms (Bouwer 1987) are warranted to further evaluate the role of biotic factors in the dynamics of POM transport and deposition.

In addition, our results suggest that it is highly improbable that filter-feeding Hydropsyche and Simuliidae regulate the downstream availability of transported POM in most stream ecosystems. We suspect that downstream self-limitation is rare and probably limited to locations where dense aggregations occur in shallow water, such as in the system described by Wotton et al. (1996). But even in the relatively small UBC (2.7-4.4 L s $\left.{ }^{-1}\right)$, where Simuliidae are present at densities of 2,000-3,000 $\mathrm{m}^{-2}$, filtering activity was responsible for a maximum of $11 \%$ of all deposition that occurred (based on statistically significant ${ }^{14} \mathrm{C}$ uptake). In most streams, the influence of filter-feeders will likely lessen and become negligible as discharge, depth, and POM concentration increase.

\section{References}

ARnQvist, G., AND D. Wooster. 1995. Meta-analysis: Synthesizing research findings in ecology and evolution. Trends Ecol. Evol. 6: 236-240. 
Bouwer, E. J. 1987. Theoretical investigations of particle deposition in biofilm systems. Water Resour. Res. 19: 732-738.

Bunt, C. M., H. J. Macisaac, And W. G. Sprules. 1993. Pumping rates and projected filtering impacts of juvenile zebra mussels (Dreissena polymorpha) in western Lake Erie. Can. J. Fish. Aquat. Sci. 50: 1017-1022.

Canter-Lund, H., And J. W. G. Lund. 1995. Freshwater algae: Their microscopic world explored. Biopress.

ChAndler, D. C. 1937. Fate of typical lake plankton in streams. Ecol. Monogr. 4: 445-479.

Cloern, J. E. 1982. Does the benthos control phytoplankton biomass in South San Francisco Bay? Mar. Ecol. Prog. Ser. 9: 191-202.

Cushing, C. E., G. W. Minshall, and J. D. Newbold. 1993. Transport dynamics of fine particulate organic matter in two Idaho streams. Limnol. Oceanogr. 38: 1101-1115.

Dame, R. F., R. G. Zingmark, And E. Haskin. 1984. Oyster reefs as processors of estuarine materials. J. Exp. Mar. Biol. Ecol. 171: 251-258.

Frèchette, M., AND E. Bourget. 1985. Food-limited growth of Mytilus edulis L. in relation to the benthic boundary layer. Can. J. Fish. Aquat. Sci. 42: 1166-1170.

Fuller, R. L., R. J. Mackay, ANd H. B. N. Hynes. 1983. Seston capture by Hydropsyche betteni nets (Trichoptera; Hydropsychidae). Arch. Hydrobiol. 97: 251-261.

GeORgIAN, T. J., AND J. H. ThORP. 1992. Effects of microhabitat selection on feeding rates of net-spinning caddisfly larvae. Ecology 73: 229-240.

— net-spinning caddisflies. Oikos 36: 147-157.

Gurevitch, J., AND L. V. Hedges. 1993. Meta-analysis: Combining the results of independent experiments, p. 378-398. In S. M. Scheiner and J. Gurevitch [eds.], Design and analysis of ecological experiments. Chapman \& Hall.

$\longrightarrow$, AND —. 1999. Statistical issues in ecological metaanalysis. Ecology 80: 1142-1149.

Haefner, J. D., And J. B. Wallace. 1981. Production and potential seston utilization by Parapsyche cardis and Diplonectra modesta (Trichoptera: Hydropsychidae) in two streams draining contrasting southern Appalachian watersheds. Environ. Entomol. 10: 433-441.

Hall, R. O., C. L. Peredney, and J. L. Meyer. 1996. The effect of invertebrate consumption on bacterial transport in a mountain stream. Limnol. Oceanogr. 41: 1180-1187.

Hershey, A. E., R. W. Merritt, M. C. Miller, and J. S. McCrea. 1996. Organic matter processing by larval black flies in a temperate woodland stream. Oikos 75: 524-532.

KöHLER, J., AND S. Bosse. 1998. Growth and losses of phytoplankton studies with a new dialysis chamber technique along the river Spree. Arch. Hydrobiol. 142: 1-19.

MacioleK, J. A., And M. G. TunZI. 1968. Microseston dynamics in a simple Sierra Nevada lake-stream system. Ecology 49: 6075.

McCullough, D. A., G. W. Minshall, And C. E. Cushing. 1979a. Bioenergetics of lotic filter-feeding insects Simulium spp. (Diptera) and Hydropsyche occidentalis (Trichoptera) and their function in controlling organic transport in streams. Ecology 60: 585-596. ers. Ecology 60: 1075 .

Miller, J., AND T. Georgian. 1992. Estimation of fine particle transport in streams using pollen as a seston analog. J. North Am. Benthol. Soc. 11: 172-180.

Minshall, G. W., S. A. Thomas, J. D. Newbold, M. T. MonaghAN, AND C. E. Cushing. 2000. Physical influences on organic particle transport and deposition in streams. J. North Am. Benthol. Soc. 19: 1-16.

Morin, A., C. Black, A. Chalifour, J. Boisvert, and R. H. PeTERS. 1988. Effect of black fly ingestion and assimilation on seston transport in a Quebec lake outlet. Can. J. Fish. Aquat. Sci. 45: 705-714.

NaIMAN, R. J. 1983. The influence of stream size on the food quality of seston. Can. J. Zool. 61: 1995-2010.

Nakamura, M., M. Yamamuro, M. IshiKawa, And H. NishimuRA. 1988. Role of the bivalve Corbicula japonica in the nitrogen cycle in a mesohaline lagoon. Mar. Biol. 99: 369-374.

Newbold, J. D., C. E. Cushing, and G. W. Minshall. 1991. Use of ${ }^{14} \mathrm{C}$ label to study fine particulate organic matter dynamics in flowing water, p. 493-501. In R. A. Baker [ed.], Organic substances and sediments in water. V. 2. Processes and analytical. Lewis.

, P. J. Mulholland, J. W. Elwood, and R. V. O’Neill. 1982. Organic carbon spiralling in stream ecosystems. Oikos 38: $266-272$.

PARKer, C. R., AND J. R. Voshell. 1983. Production of filter-feeding Trichoptera in an impounded and a free-flowing river. Can. J. Zool. 61: 70-87.

Peterson, C. H., And R. Black. 1987. Resource depletion by active suspension feeders on tidal flats: Influence of local density and tidal elevation. Limnol. Oceanogr. 32: 143-166.

Prins, T. C., A. C. SmaAl, And R. F. Dame. 1998. A review of the feedbacks between bivalve grazing and ecosystem processes. Aquat. Ecol. 31: 349-359.

Sheldon, A. L., AND M. W. Oswood. 1977. Blackfly (Diptera: Simuliidae) abundance in a lake outlet: Test of a predictive model. Hydrobiologia 56: 113-120.

Strayer, D. L., N. F. Caraco, J. J. Cole, S. Findlay, and M. L. PACE. 1999. Transformation of freshwater ecosystems by bivalves: A case study of zebra mussels in the Hudson River. Bioscience 49: 19-27.

Stream Solute Workshop. 1990. Concepts and methods for assessing solute dynamics in stream ecosystems. J. North Am. Benthol. Soc. 9: 95-119.

Thomas, S. A., J. D. Newbold, M. T. Monaghan, G. W. MinShall, T. Georgian, AND C. E. Cushing. In press. The influence of particle size on seston deposition in streams. Limnol. Oceanogr.

Wallace, J. B., And R. W. Merritt. 1980. Filter-feeding ecology of aquatic insects. Annu. Rev. Entomol. 25: 103-132.

—, J. R. Webster, AND W. R. Woodall. 1977. The role of filter-feeders in flowing waters. Arch. Hydrobiol. 79: 506-532.

Webster, J. R., E. F. Benfield, T. P. Ehrman, M. A. Schaeffer, J. L. TANK, J. J. Hutchens, AND D. J. D’Angelo. 1999. What happens to allochthonous material that falls into streams? A synthesis of new and published information from Coweeta. Freshwater Biol. 41: 687-705.

WelKer, M., AND N. WALZ. 1998. Can mussels control the plankton in rivers? - a planktonological approach applying a Lagrangian sampling strategy. Limnol. Oceanogr. 43: 753-762.

Wilkinson, S. B., W. Zheng, J. R. Allen, N. J. Fielding, V. C. Wanstall, G. Russell, and S. J. Hawkins. 1996. Water quality improvements in Liverpool docks: The role of filterfeeders in algal and nutrient dynamics. Mar. Ecol. 17: 197211.

Wotton, R. S. 1978. Growth, respiration, and assimilation of blackfly larvae (Diptera: Simuliidae) in a lake outlet in Finland. Oecologia 33: 279-290.

. 1992. Feeding by blackfly larvae (Diptera: Simuliidae) forming dense aggregations at lake outlets. Freshwater Biol. 27: $139-149$. 
1994. The biology of particles in aquatic systems. CRC. , C. P. Joicey, AND B. MalmQvist. 1996. Spiralling of particles by suspension feeders in a small lake-outlet stream. Can. J. Fish. Aquat. Sci. 74: 758-761.

, B. MalmQvist, T. MuotKa, And K. Larsson. 1998. Fecal pellets from a dense aggregation of suspension-feeders in a stream: An example of ecosystem engineering. Limnol. Oceanogr. 43: 719-725.

Received: 24 July 2000 Accepted: 12 March 2001 Amended: 10 April 2001 